\title{
Karakteristik Anak Dengan Kejadian Stunting
}

\section{Characteristics of Children with Stunting}

\author{
Astik Umiyah $^{1}$, Azizatul Hamidiyah ${ }^{2}$ \\ 1,2Program Studi Kebidanan, Fakultas Ilmu Kesehatan, Universitas Ibrahimy \\ ${ }^{1}$ Email: astik.umiyah86@gmail.com
}

\begin{abstract}
ABSTRAK
Indonesia menduduki ranking kelima Stunting di dunia. Stunting memberikan dampak jangka panjang baik secara individual maupun sosial, termasuk berkurangnya perkembangan fungsi kognitif \& fisik, rendahnya produktivitas, dan meningkatkan risiko penyakit degeneratif seperti diabetes. Situbondo juga merupakan Kabupaten dengan peringkat ketiga kasus stunting di Jawa Timur. Tujuan penelitian ini yaitu untuk mengetahui hubungan karakteristik anak dengan kejadian stunting pada balita di Wilayah Kerja Puskesmas Banyuputih Kabupaten Situbondo. Penelitian ini merupakan penelitian kuantitatif dengan desain crossectional. Sampel dalam penelitian yaitu berjumlah 274 balita di Wilayah Kerja Puskesmas Banyuputih dengan kriteria inklusi dan ekslusi. Teknik pengambilan sampel menggunakan proportional random sampling. Instrumen peneitian ini menggunakan lembar observasi dalam pengumpulan variabel independen dan dependen. Hasil penelitian menunjukkan bahwa ada hubungan antara berat badan lahir dengan kejadian stunting dengan nilai Pvalue $=0,009(\mathrm{P} \leq 0,05)$. Sedangkan sebaliknya untuk usia (Pvalue 0,095), jenis kelamin (Pvalue 0,512), dan panjang badan lahir (Pvalue $0,334)$ tidak ada hubungan dengan kejadian stunting.
\end{abstract}

Kata kunci: Stunting, Karakteristik Anak, Balita

\begin{abstract}
Indonesia ranks the 5th most stunting in the world. Stunting has long-term impacts both individually and socially, including reduced cognitive \& physical development, lower productivity, and increased risk of degenerative diseases such as diabetes. Situbondo is also the district with the third rank of stunting cases in East Java. The purpose of this study was to determine the relationship between child characteristics and the incidence of stunting in children under five in the Banyuputih Health Center, Situbondo Regency. This research was a quantitative study with a cross-sectional design. The sample in the study was 274 children under five in the Banyuputih Health Center working area with inclusion and exclusion criteria. The sampling technique used was proportional random sampling. This research instrument uses an observation sheet in collecting the independent and dependent variables. The results showed that there was relationship between birth weight and the incidence of stunting with a value of Pvalue $=0.009(P \leq 0.05)$. On the other hand, age (Pvalue 0.095), gender (Pvalue 0.512), and body length (Pvalue 0.334) had no relationship with the incidence of stunting.
\end{abstract}

Keywords: Stunting, Characteristics of Children, Children

\section{PENDAHULUAN}

Stunting merupakan masalah gizi kronik pada anak, yaitu keadaan tubuh yang pendek dan sangat pendek yaitu melebihi defisit -2SD sehingga menyebabkan kegagalan memiliki tinggi badan normal sesuai dengan usia anak (Proverawati \& Wati, 2011).

Pada Global Nutrition Targets

2025, Stunting merupakan kejadian global, diperkirakan 171 juta hingga 314 juta anak berumur di bawah lima 
tahun mengalami Stunting dan 90\% di negara Benua Afrika dan Asia . Global Nutrition Report menunjukkan Indonesia masukdalam 17 dari 117 negara, yang mempunyai tiga masalah gizi (Stunting, wasting dan overweight) pada balita (WHO, 2014).

Dampak balita yang mengalami Stunting tidak hanya memiliki pertumbuhan yang tidak optimal, tetapi juga mengalami kesulitan dalam mencapai perkembangan fisik dan kognitif yang optimal, memiliki tingkat kecerdasan tidak maksimal, lebih rentan terkena penyakit (pada saat dewasa berisiko adanya gangguan metabolisme lebih cepat seperti diabetes, hipertensi), dan menurunnya produktivitas. Pada akhirnya secara luas Stunting akan dapat menghambat pertumbuhan ekonomi, meningkatkan kemiskinan dan memperlebar ketimpangan (TNP2K, 2017).

Banyak faktor penyebab Stunting, diantaranya merupakan efek kurangnya asupan energi dan gizi serta infeksi. Faktor rumah tangga dan keluarga, MP ASI dan menyusui juga merupakan faktor langsung penyebab Stunting (Stewart, et al., 2013).

Berdasarkan hasil Riskesdas (2018), Stunting di Indonesia masih tinggi walaupun telah mengalami penurunan pada tahun 2018 dengan prevalensi sebesar 30,8\% dibandingkan dengan tahun $2013(37,2 \%)$ dan tahun 2010 (35,6\%). Dimana prevalensi pendek sebesar 30,8\% pada tahun 2018 terdiri dari $11,5 \%$ sangat pendek dan 19,3\% pendek. Dengan jumlah tersebut, Indonesia menduduki peringkat ke-5 terbanyak Stunting di dunia (keadaan ini hanya lebih baik dari India, Tiongkok, Nigeria, dan Pakistan). Sedangkan Jawa Timur merupakan provinsi yang memiliki prevalensi tinggi yaitu 26,7\%. (Direktorat Gizi Masyarakat Kemenkes RI, 2017).

Kabupaten Situbondo memiliki prevalensi Stunting yang tinggi dan terus meningkat. Situbondo juga merupakan Kabupaten dengan peringkat ketiga kasus Stunting di Jawa Timur. Berdasarkan Data Pemantauan Status Gizi Provinsi Jawa Timur Tahun 2016, Kabupaten Situbondo memiliki prevalensi balita Stunting sebesar 23,0\%, Tahun 2017 sebesar 30,5\% dan Per Februari 2018 dari 44.386 balita yang tercatat sebanyak 30,3\% mengalami Stunting.

Hasil wawancara dengan bagian data dan informasi Dinas Kesehatan Kabupaten Situbondo, menyatakan 
selama ini tidak ada pencatatan khusus Stunting (TB/U) balita. Sampai Tahun 2018, hanya mencukupkan data Survey Pemantauan Status Gizi yang dilakukan oleh Provinsi setiap tahun. Dan Baru per Tahun 2019 dilakukan pencatatan jumlah TB/U untuk deteksi Stunting, itupun hanya pada bulan timbang saja (Februari dan Agustus). Sehingga belum ada analisis khusus per Puskesmas/ Kecamatan terkait kasus Stunting di Situbondo hingga tahun 2019.

Berdasarkan laporan bulan timbang Februari 2019, Puskesmas Banyuputih merupakan Puskesmas yang memiliki angka balita Stunting tertinggi di Kabupaten Situbondo yaitu sebesar $42,7 \%$ dengan rincian 25,21 balita sangat pendek dan $17,49 \%$ pendek (Puskesmas Banyuputih, 2019).

Tujuan penelitian ini yaitu untuk mengetahui hubungan karakteristik anak dengan kejadian stunting balita di Wilayah Kerja Puskesmas Banyuputih Kabupaten Situbondo.

\section{METODE PENELITIAN}

Penelitian ini merupakan penelitian kuantitatif dengan desain crossectional. Lokasi penelitian dilakukan di Wilayah Kerja Puskesmas Banyuputih Kabupaten Situbondo.
Waktu penelitian dilakukan selama 10 bulan pada Tahun 2020.

Populasi dalam penelitian ini adalah seluruh Balita yang dilakukan pengukuran TB/U di Wilayah Kerja Puskesmas Banyuputih. Sampel dalam penelitian yaitu 274 balita di Wilayah Kerja Puskesmas Banyuputih dengan kriteria inklusi dan ekslusi. Sampel dihitung menggunakan rumus (Lemeshow, 1997).

Kriteri Inklusi,

1. Balita berusia 0-59 Bulan.

2. Balita masuk dalam data yang dilakukan pengukuran $\mathrm{TB} / \mathrm{U}$ pada bulan timbang terakhir.

3. Balita memiliki kelengkapan data pendukung.

Kriteria Ekslusi,

1. Data pendukung yang tidak lengkap.

Teknik pengambilan sampel menggunakan proportional random sampling. Instrumen yang digunakan dalam penelitian ini adalah lembar observasi, dokumen pendukung berupa kohort Balita, Buku KIA, Laporan KIA dan Gizi.

Dalam penelitian ini dilakukan analisis univariat dan bivariat. Analisis univariat dilakukan pada tiap variabel dari hasil penelitian dengan 


\begin{tabular}{|c|c|c|c|c|c|c|c|c|}
\hline \multirow{3}{*}{ No. } & \multirow{3}{*}{ Keterangan } & \multicolumn{4}{|c|}{ Status PB/U } & \multirow{2}{*}{\multicolumn{2}{|c|}{ Total }} & \multirow{3}{*}{ Pvalue } \\
\hline & & \multicolumn{2}{|c|}{ Normal } & \multicolumn{2}{|c|}{ Total } & & & \\
\hline & & $\mathbf{N}$ & $\%$ & $\mathbf{N}$ & $\%$ & $\mathbf{N}$ & $\%$ & \\
\hline \multicolumn{9}{|c|}{ Jenis Kelamin } \\
\hline 1 & Laki-Laki & 89 & 72 & 35 & 28 & 124 & 100 & \multirow{3}{*}{0,512} \\
\hline 2 & Perempuan & 114 & 76 & 36 & 24 & 150 & 100 & \\
\hline & Total & 203 & 74 & 71 & 26 & 274 & 100 & \\
\hline \multicolumn{9}{|c|}{ Berat Badan Lahir } \\
\hline 1 & $\geq 2500 \mathrm{gr}$ & 195 & 76 & 61 & 24 & 256 & 100 & \multirow{3}{*}{0,009} \\
\hline 2 & $<2500 \mathrm{gr}$ & 8 & 44 & 10 & 56 & 18 & 100 & \\
\hline & Total & 203 & 74 & 71 & 26 & 274 & 100 & \\
\hline \multicolumn{9}{|c|}{ Panjang Badan Lahir } \\
\hline 1 & $\geq 48 \mathrm{~cm}$ & 167 & 76 & 54 & 24 & 221 & 100 & \multirow{3}{*}{0,334} \\
\hline 2 & $<48 \mathrm{~cm}$ & 36 & 68 & 17 & 32 & 53 & 100 & \\
\hline & Total & 203 & 74 & 71 & 26 & 274 & 100 & \\
\hline
\end{tabular}

Berdasarkan Tabel 3 menunjukkan bahwa hasil uji statistik berat badan lahir diperoleh nilai Pvalue $=0,009(\mathrm{P} \leq 0,05)$, dengan derajat kemaknaan $\alpha$ (5\%), maka dapat disimpulkan bahwa hipotesis alternatif (Ha) diterima atau hipotesis null (Ho) ditolak yang menunjukkan adanya hubungan antara berat badan lahir dengan kejadian stunting. Sedangkan sebaliknya untuk usia (Pvalue 0,095), jenis kelamin (Pvalue 0,512), dan panjang badan lahir (Pvalue 0,334) tidak ada hubungan dengan kejadian stunting.

Hasil ini penelitian sebagaimana menurut Paudel, et al (2012) yang menujukkan bahwa Berat badan lahir kurang dari 2500gr mempunyai risiko yang lebih tinggi untuk menjadi stunting.

\section{SIMPULAN DAN SARAN}

Hasil penelitian menunjukkan bahwa ada hubungan antara berat badan lahir dengan kejadian stunting Sedangkan untuk usia, jenis kelamin, dan panjang badan tidak ada hubungan dengan kejadian stunting. Sehingga perlu menjadi perhatian khusus bagi para ibu untuk memaksimalkan nutrisi selama kehamilan. Dan bagi Puskesmas untuk memaksimalkan kunjungan ANC dengan memberikan edukasi dan program dalam upaya mencegah kejadian BBLR.

\section{DAFTAR PUSTAKA}

ACC/SCN, 2000. 4th Report - The World Nutrition Situation: Nutrition throughout the Life Cycle, Geneva: s.n.

Almatsier, S., 2009. Prinsip Dasar Ilmu Gizi. Jakarta: Gramedia. 
Bhutta, Z. et.al., 2013. vidence-based interventions for improvement of maternal and child nutrition: what can be done and at what cost? Lancet Lond. Engl. Lancet Nutrition Interventions Review Group, Maternal and Child Nutrition Study Group, Volume 328 , p. $452-477$.

Bishwakarma, R., 2011. Spacial Inequality in Children Nutrition in Nepal : Implication of Regional Context and Individual /Household Composition, United State: Disertation University of Maryland Colleged Park US.

Direktorat Gizi Masyarakat Kemenkes RI, 2016. Buku Saku Pemantauan Status Gizi Tahun 2017. Jakarta: Kemenkes RI

Direktorat Gizi Masyarakat Kemenkes RI, 2017. Buku Saku Pemantauan Status Gizi Tahun 2017. Jakarta: Kemenkes RI.

Fikadu, T., Assegid, S. \& Dube, L., 2014. Factor Associated with Stunting Among Children Age 24 to 59 month in Meskan District, Gurage Zone, South Ethiopia : A Case Control Study. BMC Public Health, 14(800).

Kementrian Kesehatan RI, 2010. Riset Kesehatan Dasar, Jakarta: Badan Penelitian dan Pengembangan Kemenkes RI.

Kementrian Kesehatan RI, 2013. Riset Kesehatan Dasar, Jakarta:
Badan Penelitian dan Pengembangan Kemenkes RI.

Lemeshow, 1997. Besar Sampel dalam Penelitian Kesehatan. Yogyakarta: UGM.

Lestari, W. M. A. R. Z., 2014. Faktor risiko stunting pada anak umur 6-24 bulan di kecamatan Penanggalan kota Subulussalam provinsi Aceh. J. GIZI Indonesia, Volume 3, p. 126134.

Meilyasari, F. \& Isnawati, M., 2014. Faktor Risiko Terjadinya Stunting pada Bayi Usia 12 Bulan di Desa Purwokerto Kecamatan Patebon Kabupaten Kendal. Journal of Nutrition College, 3(2), pp. 16-25.

Muchina, E. \& Waithaka, P., 2010. Relationship between breastfeeding practices and nutritional status of children aged 0-24 months in Nairobi, Kenya. Afr. J. Food Agric. Nutr. Dev.

Nadiyah, N. B. D. M. D., 2014. Faktor Risiko Stunting Pada Anak Usia 0-23 Bulan Di Provinsi Bali, Jawa Barat, Dan Nusa Tenggara Timur. J. Gizi Dan Pangan, Volume 9.

Nasikhah, R. \& Margawati, A., 2012. Faktor Risiko Kejadian Stunting pad aBalita Usia 24-36 Bulan di Kecamatan Semarang Timur. Journal of Nutrition College, 1(1). 
Ni'mah, K. \& Siti, R., 2015. Faktor yang Berhubungan dengan Kejadian Stunting. Media Gizi Indonesia, 10(1), pp. 13-19.

Oktarina, Z. S. T., 2014. Faktor Risiko Stunting Pada Balita (24-59). J. Gizi Dan Pangan, Volume 8.

Paudel, R. et al., 2012. Risk Factors for Stunting among Children : An COmmunity Based Case Control Study in Nepal. Kahmandu University Medical Journal, 10(3), pp. 18-24.

Pratiwi, P., 2013. Panjang lahir sebagai faktor dominan kejadian stunting pada balita usia 12-26 bulan di Desa Talagamuya Kabupaten Karawang tahun 2013, Tesis, Depok: Universitas Indonesia, Fakultas Kesehatan Masyarakat.

Proverawati, A. \& Wati, E., 2011. Ilmu Gizi untuk Keperawatan dan Gizi Kesehatan. Yogyakarta: Nuha Medika.

Pusdatin Kementrian Kesehatan RI, 2018. Situasi Balita Pendek (Stunting) di Indonesia, Jakarta: Buletin Jendela Data dan Informasi Kesehatan.
Puskesmas Banyuputih, 2019. Laporan Bulanan, Situbondo: Puskesmas Banyuputih.

Rosmanindar, E., 2013. Asupan protein sebagai faktor dominan terjadinya stunting pada anak 736 bulan di wilayah Puskesmas Pancoran Mas kota Depok tahun 2013, Tesis, Depok: Universitas Indonesia, Fakultas Kesehatan Masyarakat.

Stewart, C. et al., 2013. Contextualising complementary feeding in a broader framework for stunting prevention. Maternal and Child Nutrition, 9(2), pp. 27-45.

TNP2K, 2017. 100 Kabupaten/Kota Prioritas untuk Intervensi Anak Kerdil (Stunting). Jakarta: Sekretariat Wakil Presiden Indonesia.

WHO, 2014. Global Nutrition Targets 2025: Breestfeeding Policy Brief. [Online] Available at: http://www.who.int/nutrition/pu blications/globaltarget2025_poli cybrief_breastfeeding/en/

WHO, 2014. WHA Global Nutrition Targets 2025: Stunting Policy Brief. s.l.:World. 